\title{
Peningkatan Kesejahteraan Psikologis Wanita Menikah dengan Gangguan Fertilitas Idiopatik melalui Terapi Narima Ing Pandum
}

\author{
Astrini Arimurti Suhita ${ }^{1} \mathcal{E}$ Subandi ${ }^{2}$ \\ Fakultas Psikologi Universitas Gadjah Mada
}

\begin{abstract}
Conceiving a child in marriage is one factor influencing well-being. The inability to have a child means to pressure and suffering for the couple, especially toward women with idiopathic infertility. This study aimed to investigate the influence of Narima Ing Pandum (NIP) therapy. NIP was developed based on Javanese values of sabar (patience), syukur (gratitude) and narima (acceptance). This study used a single case A-B-A design. Psychological well-being and NIP were measured using NIP checklist and psychological well-being checklist. Visual inspection and descriptive analysis were used to interpret the data. Result indicated that NIP therapy increased the psychological well being of married women with idiopathic infertility, marked by the increasing of NIP values of the two participants.
\end{abstract}

Keywords: narima ing pandum; psychological well-being; idiopathic infertility

Abstrak. Tidak setiap pasangan dapat dengan mudah memiliki keturunan, di mana salah satunya disebabkan karena masalah infertilitas. Meskipun infertilitas ini dapat dialami oleh kedua belah pihak, hanya saja banyak penelitian menemukan bila beban akan infertilitas ini lebih banyak dialami oleh wanita, terlebih wanita dengan gangguan fertilitas idiopatik. Adanya beban yang besar dan banyak berdampak pada penurunan kesejahteraan psikologis mereka. Penelitian ini bertujuan untuk mengetahui pengaruh terapi Narima Ing Pandum (NIP). Responden dalam penelitian ini berjumlah dua orang. NIP dikembangkan berdasarkan nilai-nilai Jawa yakni sabar, syukur dan narima. Desain penelitian menggunakan single case A-B-A. Kesejahteraan psikologis diukur menggunakan ceklis kesejahteraan psikologis, sedangkan sikap NIP diukur mengunakan ceklis NIP. Hasil analisis data menggunakan visual inspection dan analisis deskriptif menemukan bahwa terapi NIP dapat meningkatkan kesejahteraan psikologis wanita menikah dengan gangguan fertilitas idiopatik seiring dengan meningkatnya pula nilai-nilai NIP dalam diri partisipan.

Kata kunci: narima ing pandum; kesejahteraan psikologis; gangguan fertilitas idiopatik

Dalam menjalankan hubungan perkawinan, setiap individu tentunya memiliki harapan yang ingin dicapai guna mendapatkan suatu kepuasan, baik secara pribadi maupun hubungan. Duvall \& Miller (1985)

\footnotetext{
${ }^{1}$ Korespondensi mengenai isi artikel ini dapat dilakukan melalui astrini.arimurti.s@mail.ugm.ac.id 2 Atau melalui subandi@ugm.ac.id
}

menyebutkan, terdapat beberapa faktor yang dapat memengaruhi kepuasan dan kesejahteraan, baik bagi individu ataupun pasangan dalam menjalani kehidupan perkawinan seperti: komunikasi, kepribadian pasangan, kemampuan menyelesaikan konflik, kebersamaan, keintiman, seksualitas, agama, hubungan dengan mertua, komitmen bersama dan anak. Secara lebih jauh, Duvall \& Miller 
(1985) menjelaskan bila dari sekian banyak faktor yang ada, anak merupakan salah satu faktor terpenting dalam pernikahan. Hal tersebut disebabkan karena kehadiran anak dalam pernikahan dirasa merupakan hal yang dapat membawa banyak dampak positif.

Dalam kacamata budaya
masyarakat Indonesia, Moeloek (1986) menyebutkan bila kehadiran anak dalam kehidupan perkawinan menunjukkan suatu gambaran ideal dari sebuah keluarga. Di samping itu, dari segi sisi budaya, sosial dan agama yang ada di Indonesia juga terdapat anggapan bila anak memiliki beberapa fungsi penting dalam keluarga seperti simbol kesuburan dan keberhasilan, pelanjut keturunan, sebagai teman dan penghibur, amanat dan anugrah dari Tuhan serta penolong orangtua di dunia dan akhirat (Moeloek, 1986). Beberapa penelitian yang dilakukan di berbagai daerah di Indonesia pun juga menunjukkan hal serupa, bila anak dianggap dapat membawa nilai-nilai positif yang kuat, baik bagi individu ataupun pasangan yang telah menikah (Singarimbun, Darroch \& Meyer, 1997; Hartoyo, Latifah \& Mulyani, 2011; Oktriyanto, Puspitawati \& Muflikhati, 2015). Hal-hal tersebut yang kemudian dirasa menjadi alasan mengapa banyak pasangan sangat berusaha untuk mendapatkan keturunan setelah menikah.

Walaupun kehadiran seorang anak memiliki hubungan yang kuat dengan kesejahteraan individu yang telah menikah, namun tidak semua pasangan dapat langsung dikaruniai anak seperti yang diinginkan. Sebagian pasangan dapat dengan mudah memiliki keturunan, sebagian lain perlu usaha yang cukup keras untuk mendapatkan keturunan, dan sebagian pasangan yang lain bahkan tidak mampu mewujudkan keinginan untuk mendapatkan keturunan tersebut. Ketidakmampuan pasangan untuk memiliki anak salah satunya disebabkan karena adanya gangguan fertilitas.

Menurut pengertiannya, gangguan fertilitas atau yang biasa dikenal dengan istilah infertilitas merupakan suatu gangguan di mana pasangan tidak mampu untuk memiliki anak setelah dalam jangka waktu 12-18 bulan melakukan hubungan seksual secara teratur dan tanpa menggunakan kontrasepsi (Hiferi, Perfitri, Iaui \& Pogi, 2013). Infertilitas ini sendiri menurut Hiferi et al. (2013) terbagi menjadi tiga jenis yaitu infertilitas primer, infertilitasi sekunder, dan infertilitas idiopatik. Infertilitas primer merupakan ketidakmampuan seseorang untuk mendapatkan anak yang biasanya disebabkan karena adanya masalah pada organ reproduksi. Infertilitas sekunder, merupakan ketidakmampuan seseorang (khususnya wanita) untuk mempertahankan kehamilan serta mengalami kesulitan untuk mendapatkan anak kembali setelahnya. Sedangkan infertilitas idiopatik, merupakan pasangan yang memiliki hasil normal pada setiap pemeriksaan organ reproduksi namun memiliki kesulitan dalam memiliki anak, biasanya dikarenakan adanya faktor psikologis.

Data menyebutkan, dalam kurun waktu 10 tahun belakangan ini terjadi peningkatan jumlah pasangan infertil yang tersebar di seluruh penjuru dunia. Hal tersebut dapat dilihat dari terus menurunnya angka total fertilitas atau TFR (Total Fertility Rate) dari tahun ke tahun. Di Indonesia, survei yang dilakukan oleh Departemen Kesehatan menyebutkan, angka TFR Indonesia terus mengalami penurunan. Survey terakhir yang dilakukan pada tahun 2014 menunjukkan bahwa angka TFR di Indonesia kini sebesar 2.2.

Permasalahan tentang fertilitas sebenarnya dapat dialami oleh kedua belah pihak, baik suami ataupun istri. Hanya saja 
banyak penelitian menunjukkan bahwa beban akan infertilitas lebih banyak dialami oleh seorang istri dibandingkan suami (Peterson, Newton, Rosen \& Skaggs, 2006; Draye, Wood, \& Mitchell, 2009; Haica, 2013). Hal tersebut terkait dengan adanya pandangan di masyarakat, dimana kodrat seorang wanita salah satunya adalah masalah mengandung dan melahirkan anak (Dermatoto, 2008). Wanita dianggap memiliki lebih banyak komponen biologis yang menunjang keberhaslian maupun ketidakberhasilan dalam usaha memiliki anak seperti: sel telur, indung telur, saluran telur, rahim, mulut rahim dan vagina (Dermatoto, 2008). Hal tersebutlah yang menyebabkan ketika keturunan susah diperoleh maka pihak wanita yang akan lebih banyak dituntut serta dipersalahkan. Selain itu, dengan adanya pandangan bila wanitalah yang bertanggung jawab terhadap keberhasilan ataupun kegagalan dalam memiliki anak menyebabkan adanya pula harapan yang besar pada diri seorang wanita dalam usaha memiliki anak (Dermatoto, 2008).

Tekanan mengenai infertilitas pada wanita tidak hanya berupa stigma dan pandangan dari masyarakat. Hal lain yang menjadi sumber tekanan seputar infertilitas pada wanita adalah mengenai lamanya pernikahan yang telah dijalani. Besarnya tekanan dan harapan seputar isu fertilitas biasanya timbul secara kuat setelah individu memasuki usia pernikahan tiga tahun (Smolak, 1993). Pada masa tersebut, individu yang telah menikah sudah diharapkan memiliki anak pertama, oleh karenanya, ketika sampai pada masa tersebut pasangan belum juga memiliki anak, tekanan dan harapan baik dari luar ataupun diri sendiri akan muncul dengan kuat (Smolak, 1993).

Berdasarkan hasil preliminary study yang dilakukan kepada lima orang wanita dengan gangguan fertilitas yang beragam, diketahui bila jenis dari fertilitas yang dialami juga menjadi faktor yang dapat gangguan fertilitas idiopatik merupakan gangguan yang menimbulkan tekanan psikologis yang paling tinggi dibandingkan dengan gangguan fertilitas primer ataupun sekunder. Pada gangguan fertilitas primer ataupun sekunder, wanita merasa lebih mudah pasrah dan menerima kenyataan bahwa dirinya memang tidak dapat/ kesulitan memiliki anak dikarenakan faktor biologis yang memang bermasalah. Pada wanita dengan gangguan fertilitas idiopatik, mereka merasa tidak ada yang salah dengan kondisi tubuhnya sehingga harapan untuk memiliki anak sangat besar.

Adanya tekanan yang kuat baik dari lingkungan ataupun diri sendiri dirasa menjadi faktor yang dapat menimbulkan berbagai permasalahan pada diri seorang wanita yang telah menikah. Salah satu permasalahan yang dapat timbul adalah munculnya respon stres. Respon stres atau yang biasa dikenal dengan stres merupakan suatu kondisi ketegangan mental, fisik ataupun emosional yang dihasilkan dari adanya suatu tekanan atau stressor (Pinel, 2009). Sesuai dengan pengertiannya, stres tersebut akan dapat bermanifestasi menjadi banyak bentuk, baik fisik, emosi ataupun perilaku pada individu yang mengalaminya.

Penelitian yang dilakukan oleh Rascanu \& Vladica (2012) menemukan bahwa stres akan infertilitas dapat menimbulkan adanya perasaan depresif, kecemasan, bersalah serta ketakutan dalam hubungan pernikahan dan sosial. Bahkan tekanan sosial pada wanita dengan infertilitas juga dapat menyebabkan munculnya perilaku isolasi terhadap lingkungan di sekitarnya (Rascanu \& Vladica, 2012). Penelitian yang dilakukan oleh Hidayah (2012) pun menemukan bahwa stres mengenai infertilitas merupakan salah satu faktor yang sangat memengaruhi kepuasan seorang wanita dalam menjalani hubungan perkawinan. Dengan kata lain, 
infertilitas dapat menyebabkan munculnya perasaan negatif pada wanita dalam memandang hubungan perkawinan dan sosial.

Tidak hanya berdampak pada pandangan pada lingkungan sosial dan perkawinan, penelitian yang dilakukan oleh Tuzsr, Tuncel, Goka, Bulut, Yuksel, Atan \& Goka (2010) menyebutkan bahwa adanya kondisi tertekan akan adanya infertilitas dalam pernikahan dapat memunculkan adanya simptom-simptom depresi dan kecemasan. Penurunan kesehatan secara fisik dan kualitas hidup juga dirasakan oleh wanita-wanita yang memiliki tekanan mengenai isu infertilitas (Haica, 2013; Xiaoli, et al., 2015). Penelitian lain pun juga menemukan stres akan infertilitas juga dapat menyebabkan adanya perasaan kosong dan tidak lengkap pada seorang wanita (Park \& Hill, 2014).

Adanya berbagai kondisi negatif sebagai akibat dari stres infertilitas, merupakan hal yang menunjukkan terjadinya penurunan terhadap kondisi kesejahteraan psikologis wanita menikah yang memiliki gangguan fertilitas. Hal tersebut sesuai dengan penjelasan yang dikemukakan oleh Ryff (1998) di mana kesejahteraan psikologis merupakan sesuatu hal yang lebih dari sekedar bebas distres atau gangguan mental. Secara lebih jelas, kesejahteraan psikologis diartikan sebagai suatu perasaan sejahtera yang ditandai dengan adanya sikap positif, baik terhadap diri sendiri ataupun terhadap orang lain dan lingkungan sekitar, mampu melakukan pertumbuhan dan perkembangan diri yang berkelanjutan, memiliki keyakinan bahwa dirinya memiliki tujuan, mampu secara efektif mengatur kehidupannya dan memiliki prinsip (Ryff, 1998; Ryff, 2014).

Meskipun terdapat kemungkinan penurunan kesejahteraan psikologi pada wanita menikah yang tidak mampu memiliki anak, namun hal tersebut tidaklah mutlak terjadi pada setiap wanita. Hal tersebut tergantung dari bagaimana koping seorang individu dalam menghadapi situasi yang dialami. Garcia, Nima \& Kjell (2014) menyebutkan bahwa, kemampuan penerimaan terhadap kondisi penuh stres merupakan salah satu hal yang dapat memengaruhi kondisi kesejahteraan psikologis individu. Ketika individu mampu melakukan penerimaan terhadap kondisi yang dialami, individu tersebut cenderung memiliki kondisi kesejahteraan psikologis yang lebih baik (Garcia et al., 2014). Selain masalah penerimaan, penelitian lain juga mengungkapkan bahwa kemampuan untuk bersyukur (Wood, Froh \& Geraghty, 2010) dan sabar (Schnitker, 2012) juga memiliki dampak yang positif terhadap kondisi kesejahteraan psikologis individu dalam menghadapi situasi penuh tekanan. Oleh karena itulah, perlu dilakukan suatu program intervensi yang komprehensif, sehingga dapat meningkatkan individu terhadap situasi penuh stres dan kesejahteraan psikologisnya pun dapat ikut meningkat.

Dalam menentukan jenis intervensi yang tepat, salah satu hal yang perlu diperhatikan adalah mengenai budaya dari individu yang akan diberikan terapi. Tseng (1999) mengungkapkan bahwa budaya dan intervensi psikologi merupakan dua hal yang sebaiknya tidak terpisahkan. Hal tersebut disebabkan, budaya merupakan sesuatu nilai yang akan memengaruhi sikap individu dalam menghadapi sesuatu. Dengan adanya kesesuaian antara intervensi psikologi dengan budaya yang dianut, maka kemungkinan keberhasilan intervensi psikologi dirasa akan semakin meningkat. Senada dengan hal tersebut, White, Gibbons \& Scamberger (2006) juga mengungkapkan bahwa adanya keselarasan intervensi dengan budaya yang dipegang oleh klien akan dapat mempermudah terapis dalam menyatukan 
dan antusias pada diri klien. pemahaman serta memunculkan rasa aman

Di Indonesia, khususnya di Jawa, salah satu nilai budaya yang masih dikenal dan dianut hingga saat ini adalah sikap Narima Ing Pandum (NIP) (Endraswara, 2012). NIP merupakan salah satu pitutur luhur (sestradi) dalam masyarakat Jawa yang membantu individu menemukan pencerahan dan kesempurnaan lahir batin (Saktimulya, 2016). Menurut pengertiannya, NIP didefiniskan sebagai suatu sikap sarat nilai spiritual yang mengajarkan individu untuk mampu sadar dan menerima dengan perasaan syukur atas apa yang telah diberikan (pandum) oleh Tuhan serta memiliki keyakinan bahwa segala sesuatu yang terjadi sudah diatur (Bratawijaya, 1997; Endraswara, 2012; Suratno \& Astiyanto, 2009, Rahmat, 2017).

Adanya kesadaran bahwa hidup manusia telah memiliki jatah (pandum) masing-masing disinyalir mampu mendorong seseorang untuk lebih ikhlas, berfikiran positif serta tidak menggerutu terhadap apa yang terjadi (Suratno \& Astiyanto, 2009; Rahmat, 2017). Selain itu, NIP juga merupakan sikap yang mengajarkan individu untuk menerima secara penuh kejadian masa lalu, sekarang dan segala kemungkinan yang dapat terjadi (Endraswara, 2012; Sulaksono, 2014). Hal tersebut merupakan suatu cara untuk mengurangi kekecewaan, menghadapi kemungkinan buruk yang terjadi serta menurunkan emosi-emosi yang bersifat negatif seperti rasa marah, benci, kesal, bersalah serta cemas (Endraswara, 2012; Sulaksono, 2014). Meskipun sikap NIP mengajarkan individu untuk belajar menerima suatu kejadian, sikap NIP bukanlah suatu sikap yang mengajarkan individu untuk bersikap pasif. Hal tersebut dikarenakan, sikap NIP mengajarkan kepada seorang individu untuk tidak hanya menerima sesuatu tanpa usaha, melainkan bersama dengan usaha, kesabaran dan kebersyukuran (Sulaksono, 2014). Penelitian tentang NIP sebagai suatu psikoterapi sudah pernah dilakukan dalam rangka peningkatan kesejahteraan psikologis dan penurunan ekspresi emosi keluarga. Prasetyo (2014) menemukan bahwa terapi NIP terbukti mampu meningkatkan kondisi kesejahteraan psikologis caregiver skizofrenia yang sedang menghadapi situasi sulit. Selain itu, NIP juga telah terbukti mampu menurunkan tingkat ekspresi emosi keluarga pendamping dari pasien skizofrenia (Zulyet, 2014).

Terapi NIP yang digunakan dalam penelitian ini, disusun dengan menggunakan pendekatan humanistik. Terapi dengan menggunakan pendekatan humanistik, merupakan terapi yang bertujuan untuk membantu individu agar dapat berfungsi sepenuhnya (Roger, dalam Passer \& Smith, 2007). Terapi NIP ini dilakukan dengan cara terapis mendengarkan secara aktif terhadap cerita partisipan serta terbuka terhadap perasaan partisipan baik yang bersifat positif ataupun negatif. Terapi NIP ini bertujuan membantu partisipan untuk mengurangi distres akibat adanya ketidaksesuaian antara ideal self yang partisipan miliki dengan real self yang ada (Lihat gambar 1). Dengan adanya penurunan tingkat distres dalam diri partisipan, individu yang berfungsi penuh sehingga kesejahteraan psikologis dalam diri diharapkan partisipan dapat menjadi partisipan dapat meningkat. Berdasarkan uraian di atas, nilai-nilai yang terkandung dalam sikap NIP terbukti memiliki banyak manfaat untuk meningkatkan kondisi kesejahteraan psikologis individu. Penelitian tentang NIP sendiri juga telah terbukti mampu meningkatkan kondisi kesejahteraan psikologis. Oleh karena itu, hipotesis yang diajukan adalah Terapi Narima Ing Pandum dapat meningkatkan kesejahteraan psikologis pada wanita menikah yang memiliki gangguan fertilitas idiopatik. 


\begin{abstract}
Metode
Desain penelitian

Desain yang digunakan dalam penelitian ini adalah eksperimen single case A-B-A design dengan repeated assessment and marked changes. Desain A-B-A menggambarkan tiga fase dalam penelitian, yakni fase baseline (A) yang merupakan kondisi tanpa intervensisebelum intervensi diberikan. Fase intervensi (B) merupakan fase pemberian tritmen kepada partisipan, dan kemudian kembali pada fase baseline (A) yaitu fase tanpa intervensi - setelah intervensi selesai diberikan. Pengukuran berulang dilakukan sebelum, saat dan sesudah intervensi.
\end{abstract}

\section{Partisipan penelitian}

Partisipan dalam penelitian ini adalah dua orang wanita yang memenuhi kriteria inklusi , yaitu wanita dewasa dalam usia subur (2035 tahun), suku Jawa, memahami bahasa dan budaya Jawa, belum memiliki anak, telah menikah minimal tiga tahun dan secara teratur melakukan hubungan seksual (khususnya dalam satu tahun terakhir) tanpa adanya pemakaian kontrasepsi, tidak memiliki masalah / penyakit fisik yang berhubungan dengan reproduksi yang dinyatakan dengan keterangan dokter, dan bersedia mengikuti penelitian dengan mengisi lembar informed consent.

\section{Metode pengumpulan data}

Metode pengumpulan data dilakukan dengan meminta partisipan untuk mengisi ceklis NIP yang berjumlah 12 aitem. Ceklis NIP disusun berdasarkan 3 aspek yaitu sabar, syukur dan narima. Ceklis NIP berbentuk likert dengan lima pilihan jawaban yang dapat menunjukkan kondisi kesesuaian partisipan terhadap pernyataan dalam aitem. Ceklis kesejahteraan psikologi juga diberikan kepada partisipan untuk diisi selama proses pengumpulan data. Ceklis kesejahteraan psikologi disusun berdasarkan teori kesejahteraan psikologi oleh Ryff (1989;
2014). Selain kedua ceklis tersebut, partisipan juga diberikan lembar-lembar tugas untuk diisi pada setiap sesi intervensi. Data juga diperoleh dari lembar observasi dan hasil wawancara yang ada selama sesi intervensi diberikan.

\section{Prosedur penelitian}

Program intervensi diberikan sebanyak 8 kali sesi kepada setiap partisipan. Sesi intervensi dilakukan selama 2 kali dalam seminggu selama 4 minggu berturut-turut. Intervensi terdiri dari sesi katarsis, sesi materi sikapsikap NIP, latihan penerapan sikap NIP serta rileksasi. Intervensi dilakukan di ruang terapi yang telah ditentukan dan disepakati sebelumnya.

\section{Teknik analisis data}

Metode analisis data dari ceklis NIP dan ceklis kesejahteraan psikologi, dilakukan melalui visual inspection. Hal tersebut dilakukan untuk mengetahui perubahan yang terjadi antara sebelum, selama dan setelah intervensi. Ceklis NIP dan ceklis kesejahteraan psikologis diberikan sebanyak 14 kali, yaitu 3 kali pada fase baseline 1, 8 kali pada fase intervensi dan 3 kali pada fase baseline 2. Analisis deskriptif terhadap hasil observasi, lembar tugas serta hasil wawancara juga dilakukan untuk memperdalam pemahaman mengenai proses dan kemajuan yang dicapai oleh masingmasing partisipan.

\section{Hasil}

\section{Partisipan N}

Latar belakang

$\mathrm{N}$ merupakan perempuan berusia 35 tahun dan telah menikah selama 4 tahun. $\mathrm{N}$ mengungkapkan bila selama 4 tahun pernikahan tersebut, $\mathrm{N}$ dan suami belum juga dikaruniai momongan meskipun sudah teratur dalam melakukan hubungan seksual. Hal tersebut yang kemudian mendorong $\mathrm{N}$ dan suami melakukan berbagai cara untuk 
Stressor yang dihadapi wanita menikah dengan gangguan fertilitas idiopatik:

- Stigma negatif yang kuat pada wanita infertil

- Tekanan sosial dari lingkungan keluarga, tetangga, masyarakat

- Harapan diri sendiri yang tidak terealisasikan

\section{Intervensi Narima Ing Pandum}

- Katarsis

- Pengetahuan akan sikap sabar

Kondisi stres yang bermanifestasi menjadi:

- Munculnya perasaan-perasaan negatif pada diri sendiri seperti kecewa, sedih, marah

- Munculnya perilaku isolasi diri dari lingkungan

- Ketidakpuasan dalam hubungan pernikahan dan sosial

- Munculnya simptom depresi dan kecemasan

- Penerapan sikap sabar

- Pengetahuan sikap syukur

- Penerapan sikap syukur

- Pengetahuan sikap narima

- Penerapan sikap narima

- Lebih sabar dalam dalam menghadapi stressor yang ada.

- Lebih mampu menerima kondisi saat ini

- Lebih bersyukur dan menghargai hal-hal yang sudah dimiliki

Penurunan kondisi kesejahteraan psikologis

Meningkatnya kondisi kesejahteraan psikologi

Keterangan :

$\longrightarrow$ : menghasilkan

$\stackrel{\longrightarrow}{\longrightarrow}$ : pemberian intervensi

Gambar 1. Kerangka berfikir penelitian 


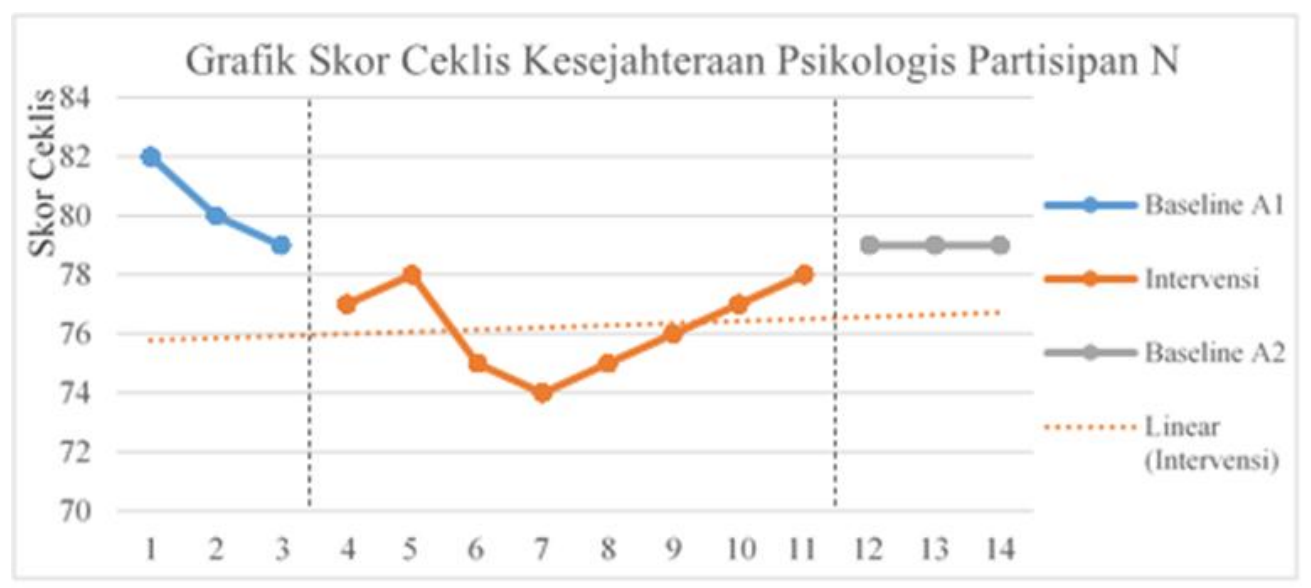

Grafik 1. Skor ceklis harian kesejahteraan psikologis

mendapatkan momongan seperti mengikuti pengobatan medis ataupun pengobatan secara alternatif. $\mathrm{N}$ mengungkapkan bila dari pemeriksaan medis yang dilakukan pada tahun kedua dalam pernikahan, tidak ditemukan adanya masalah mengenai reproduksi N. Hanya saja pada saat pemeriksaan tersebut, suami $\mathrm{N}$ diketahui memiliki masalah pada spermanya sehingga memerlukan pengobatan. Meskipun sudah melakukan pengobatan selama setahun dan dinyatakan sudah sembuh, $\mathrm{N}$ dan suami tetap belum juga dikaruniai momongan hingga saat ini.

\section{Analisis kuantitatif}

Analisis dengan menggunakan visual inspection pada kesejahteraan psikologis partisipan $\mathrm{N}$, seperti yang tertera pada grafik 1, menunjukkan adanya tren penurunan pada fase baseline 1 dengan rerata skor $M=$ 80,3 dan stabil pada persentase $90,5 \%$. Angka rerata tersebut kemudian menurun pada fase intervensi dengan besarnya skor $M=76,25$. Berdasarkan grafik 1, terlihat skor kesejahteraan partisipan $\mathrm{N}$ selama fase intervensi memang selalu lebih rendah dibandingkan selama fase baseline 1. Bahkan skor partisipan $\mathrm{N}$ sempat mengalami penurunan yang cukup banyak pada pengukuran ke 6 dan ke 7 (intervensi ke 3 dan 4), sebelum kemudian mulai mengalami peningkatan skor. Meskipun demikian, dari hasil garis trend linear skor ceklis kesejahteraan psikologis selama intervensi terlihat bila partisipan mengalami kenaikan kondisi. Pada fase baseline 2, yaitu fase setelah intervensi selesai diberikan, partisipan

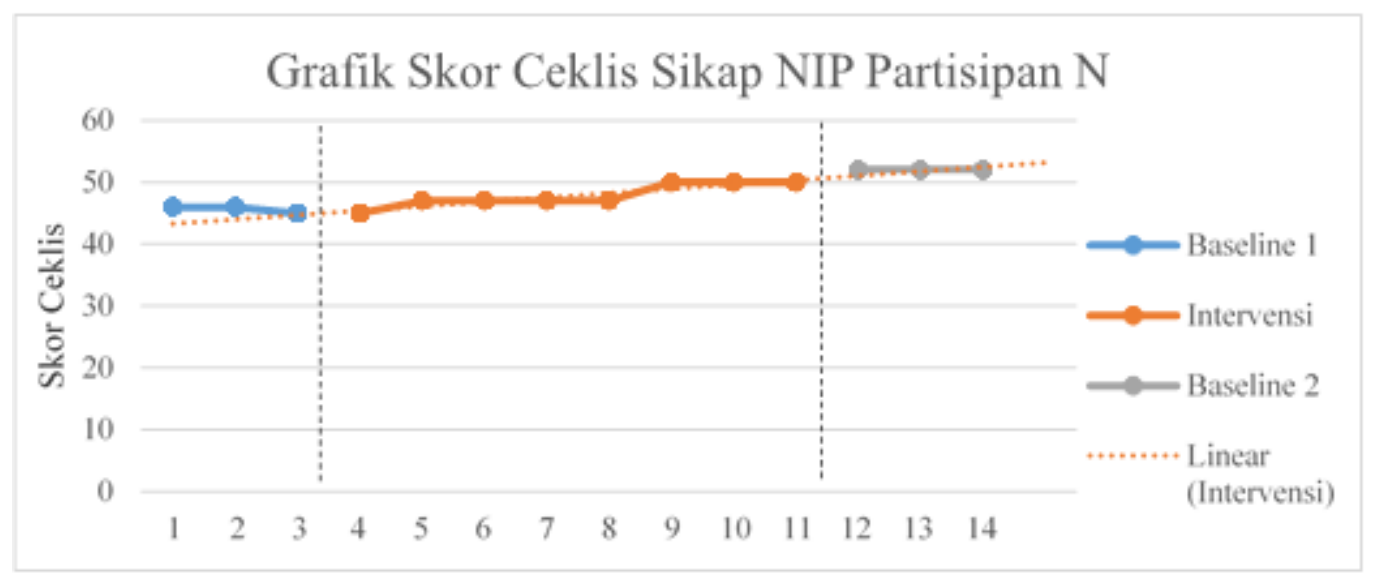

Grafik 2. Hasil skor ceklis harian sikap NIP (Cek manipulasi) 
terlihat mengalami peningkatan skor dengan besarnya skor $M=79$.

Perubahan terhadap kondisi kesejahteraan psikologis partisipan $\mathrm{N}$, menunjukkan adanya keselarasan dengan perubahan kualitas sikap NIP partisipan.

Hasil pengukuran kondisi sikapsikap NIP dalam diri partisipan juga terlihat semakin meningkat dari fase ke fase. Dari hasil pengukuran skor rerata harian sikap NIP, skor sikap NIP partisipan bergerak dari $M=45,7$ pada fase baseline 1 , menjadi $M=47,9$ pada fase intervensi dan $\mathrm{M}=52$ pada fase baseline 2. Jika dilihat dari garis trend linear seperti yang tertera pada grafik 2, partisipan terlihat mulai mengalami peningkatan sikap NIP sejak fase intervensi hingga fase paska intevensi, meskipun pada fase baseline 2 hasil sikap NIP partisipan berada dalam kondisi stabil.

Apabila dilakukan analisis secara lebih terperinci, khususnya pada perkembangan aspek sikap-sikap NIP dalam diri partisipan, ditemukan bahwa tidak semua aspek sikap NIP dalam diri partisipan mengalami peningkatan. Partisipan hanya mengalami peningkatan pada aspek sikap sabar dan sikap syukur, sedangkan aspek sikap narima dalam diri partisipan diketahui mengalami penurunan. Berdasarkan perhitungan hasil skor rerata, diketahui bila aspek sikap sabar partisipan bergerak dari angka $M=13$ pada fase baseline 1 , kemudian naik menjadi $M=13,6$ pada fase intervensi dan semakin naik menjadi $M=17$ pada fase baseline 2. Bila dilihat dari pergerakan arah grafik, seperti yang tercantum pada grafik 3 , terlihat bila sikap sabar partisipan memang cenderung mendatar pada fase baseline hingga pertengahan fase intervensi, dan mulai meningkat sejak pertengahan fase intervensi dan stabil pada fase baseline 2 .

Perhitungan skor rerata pada aspek sikap syukur pada diri partisipan $\mathrm{N}$ menunjukkan hasil $M=15,6$ pada fase baseline 1 , kemudian meningkat menjadi $M=17,5$ pada fase intervensi dan semakin meningkat menjadi $M=19$ pada fase baseline 2. Bila dilihat dari arah perkembangan garis dalam grafik, diketahui bila aspek sikap syukur pada diri partisipan cenderung fluktuatif. Aspek sikap syukur partisipan cenderung menurun pada fase baseline 1, kemudian mulai naik pada awal fase intervensi kemudian cenderung stabil pada pertengahan intervensi, sempat naik cukup tajam pada pertemuan ke 6 proses intervensi dan stabil pada fase baseline 2 .

Berbeda dengan dua sikap yang lain, sikap narima dalam diri partisipan terlihat mengalami penurunan. Dari perhitungan hasil skor rerata diketahui bila partisipan

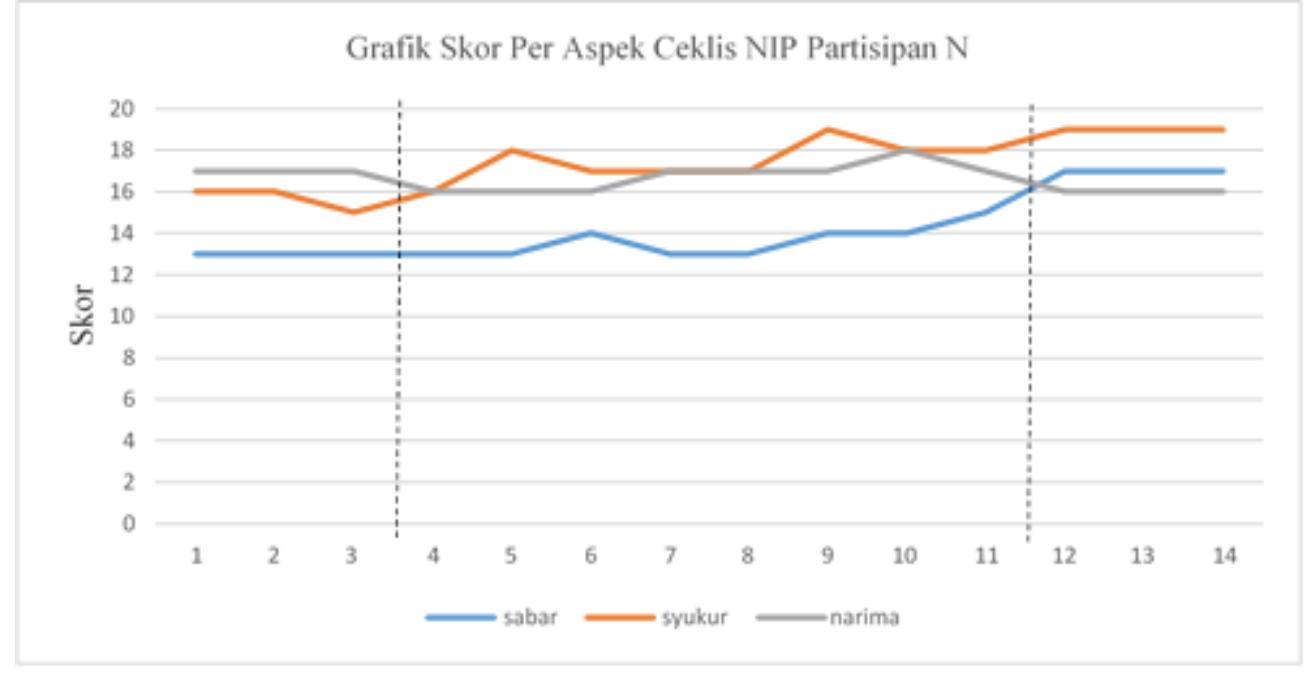

Grafik 3. Skor per aspek ceklis NIP Partisipan 
memperoleh skor $M=17$ pada fase baseline 1 , kemudian turun menjadi $M=16,7$ pada fase intervensi dan semakin turun menjadi $M=16$ pada fase baseline 2. Bila dilihat dari hasil garis grafik, seperti yang tertera pada gambar 4, diketahui bila partisipan $\mathrm{N}$ berada dalam kondisi stabil pada fase baseline 1, kemudian menurun pada fase awal intervensi, sempat sedikit naik pada fase pertengahan kemudian menurun pada fase akhir intervensi hingga baseline 2 .

Dari hal tersebut dapat disimpulkan bahwa meskipun kondisi kesejahteraan psikologis partisipan sempat menurun pada awal fase intervensi, terapi NIP mampu kembali meningkatkan kesejahteraan psikologis pada diri partisipan, seiring dengan meningkatnya pula kualitas sikapsikap NIP dalam diri partisipan khususnya sikap sabar dan syukur. Selain itu, efek dari terapi NIP masih bertahan pada diri partisipan baik terhadap sikap NIP ataupun kesejahteraan diri meskipun terapi sudah tidak lagi diberikan dan hal tersebut sangatlah bertentangan dengan nilai yang dianut N. Adanya perbedaan tersebut membuat $\mathrm{N}$ seringkali merasa sakit hati dan tidak merasa nyaman saat berinteraksi dengan mereka sehingga $\mathrm{N}$ cenderung menghindari interaksi dengan lingkungan sekitar. Adanya tekanan-tekanan tersebut menjadi tanda bila partisipan mengalami permasalahan dalam dimensi kesejahteraan psikologis yaitu pada bagian hubungan positif dengan orang lain dan pemahaman terhadap lingkungan.

Selama fase baseline 1, N mengatakan bahwa dirinya telah belajar banyak tentang penerimaan dari kajian-kajian agama yang Ia ikuti. Partisipan $\mathrm{N}$ juga sering kali mengulang-ulang pernyataan bahwa dirinya bisa menerima dan tidak merasa bermasalah dengan kondisi belum memiliki anak, karena semua itu adalah kehendak Allah. Pernyataan tersebut masih juga sering diulang hingga pertemuan ketiga. Hanya saja di sisi lain partisipan $\mathrm{N}$ juga terus mengeluhkan kondisi yang secara tidak langsung berhubungan dengan kondisi belum memiliki anak tersebut, seperti hubungan dengan mertua, ipar ataupun lingkungannya. Di saat terapis mencoba untuk meluruskan, $\mathrm{N}$ sering melakukan penyangkalan dengan berkata "Enggak mbak, enggak gitu, cuman...".

Dari hasil observasi selama pertemuan pertama hingga ketiga, diketahui pula $\mathrm{N}$ seringkali menyangkal ketika terapis mencoba merefleksikan emosi yang muncul seperti: menyatakan bila dirinya tidak mau baper (membawa perasaan) dalam memandang masalah pada dan menjawab bila sedang mengalami masuk angin saat ditanya mengapa $\mathrm{N}$ diam dan berkaca-kaca setelah bercerita.

Pada pertemuan keempat, $\mathrm{N}$ mulai dapat fokus terhadap jalannya tujuan dari intervensi diadakan. $\mathrm{N}$ juga mulai dapat terbuka baik secara komunikasi ataupun emosi, serta tidak banyak melakukan penyangkalan. Pada pertemuan keempat tersebut, $\mathrm{N}$ mengatakan bila dirinya jadi lebih menyadari bahwa dirinya masih memiliki rasa sedih, iri, ingin dan kecewa terhadap kondisinya yang belum memiliki keturunan. $\mathrm{N}$ juga mengungkapkan bila dirinya belajar banyak sudut pandang baru tentang sabar dan syukur. Kesabaran dan kebersyukuran dimaknai partisipan sebagai sesuatu yang tidak hanya selalu mengenai hal-hal yang besar-besar saja, namun juga hal-hal kecil dalam hidup.

Pada pertemuan kelima, $\mathrm{N}$ sempat mengalami kesulitan saat diajak untuk berdiskusi mengenai sikap syukur yang sudah dipelajari pada pertemuan keempat. $\mathrm{N}$ masih terlihat belum paham terhadap makna sikap syukur sehingga kesulitan saat diminta memberikan contoh. Terapis harus kembali memberikan materi dan penjelasan hingga $\mathrm{N}$ akhirnya dapat paham serta menemukan makna bila dirinya perlu bersyukur lebih 
banyak lagi terkait hal-hal kecil, menyadari lebih banyak lagi terhadap hal-hal yang dapat disyukuri oleh dirinya dan menjadi pribadi yang lebih tangguh.

Pertemuan keenam dan ketujuh berjalan dengan lancar dan sesuai dengan alur dari intervensi diadakan. Partisipan N merasa mendapatkan banyak ilmu baru dan skill baru tentang penerimaan, terutama yang berkaitan dengan kesabaran dan kebersyukuran serta memiliki keyakinan bahwa dirinya mampu menerapkan hal tersebut Pada sesi kedelapan, partisipan mengungkapkan bahwa terapi NIP membuat dirinya merasa lebih legawa dan mampu mengontrol emosinya yang cenderung fluktuatif.

Pengambilan data wawancara juga dilakukan di akhir fase baseline 2. Partisipan $\mathrm{N}$ mengungkapkan bila dirinya masih terus belajar menjadikan sikap sabar, syukur dan narima sebagai nilai yang dipegang untuk menghadapi kejadian sehari-hari. Dari keseluruhan proses terapi, bagian rileksasi merupakan hal yang paling dirasakan bermanfaat bagi partisipan $\mathrm{N}$ terutama untuk mengatur emosinya yang cenderung fluktuatif.

\section{Partisipan A}

Latar belakang

A merupakan wanita berusia 28 tahun yang sudah menjalani 4 tahun pernikahan dengan suami. Selama 4 tahun pernikahan, A dan suami sudah melakukan berbagai macam hal untuk memperoleh keturunan baik dari segi medis ataupun alternatif. Dari proses pemeriksaan secara medis, A dinyatakan sehat oleh dokter. Hanya saja suami A perlu mendapatkan pengobatan dengan vitamin dikarenakan gaya hidupnya yang kurang sehat sehingga dimungkinkan dapat memengaruhi kualitas sperma. Meskipun demikian, A dan suami dinyatakan sehat secara medis oleh dokter.

\section{Analisis kuantitatif}

Analisis kesejahteraan psikologis partisipan A menggunakan visual inspection, menunjukkan adanya tren grafik yang stabil dengan besarnya rerata skor $M=55$ pada fase baseline 1 dengan presentase kestabilan 100\%, yaitu fase sebelum terapi diberikan. Selanjutnya pada fase intervensi, yaitu ketika partisipan mulai diberikan perlakuan berupa terapi, rerata hasil skor partisipan juga terlihat mengalami kenaikan kondisi kesejateraan psikologis dengan nilai $M=68,4$. Perhitungan skor rerata pada fase baseline 2 juga menunjukkan bila partisipan semakin mengalami peningkatan kondisi kesejahteraan psikologis dengan skor $M=79,3$. Dari arah garis tren yang bergerak semakin ke kanan atas seperti yang terdapat pada grafik 4, dapat disimpulkan bila kondisi kesejahteraan psikologis terlihat mengalami peningkatan.

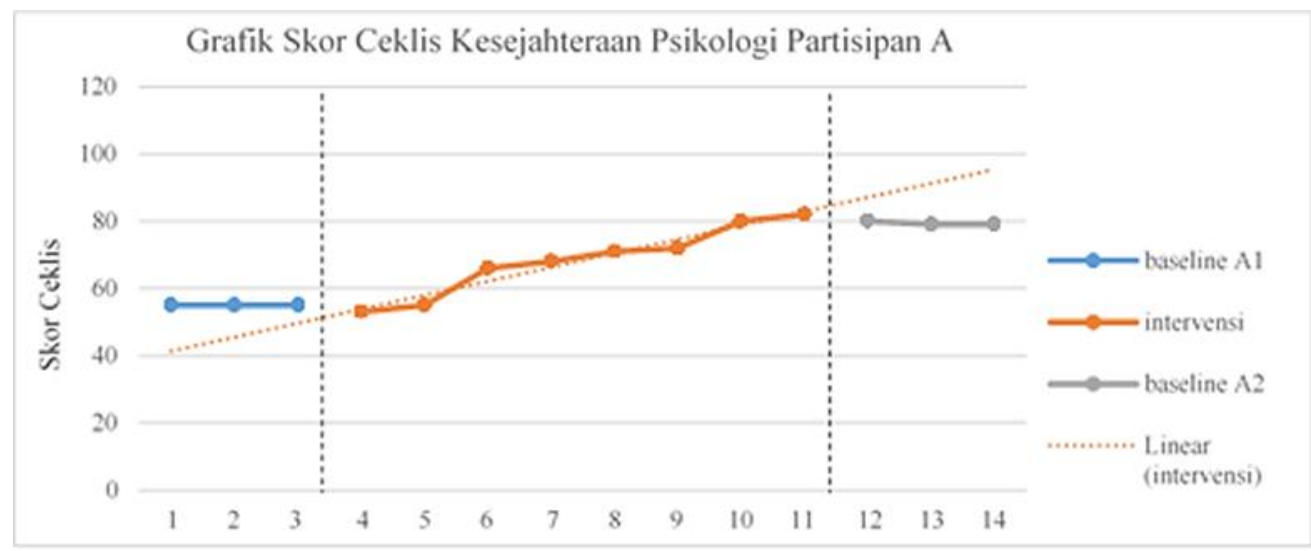

Grafik 4. Hasil ceklis harian kesejahteraan psikologis 


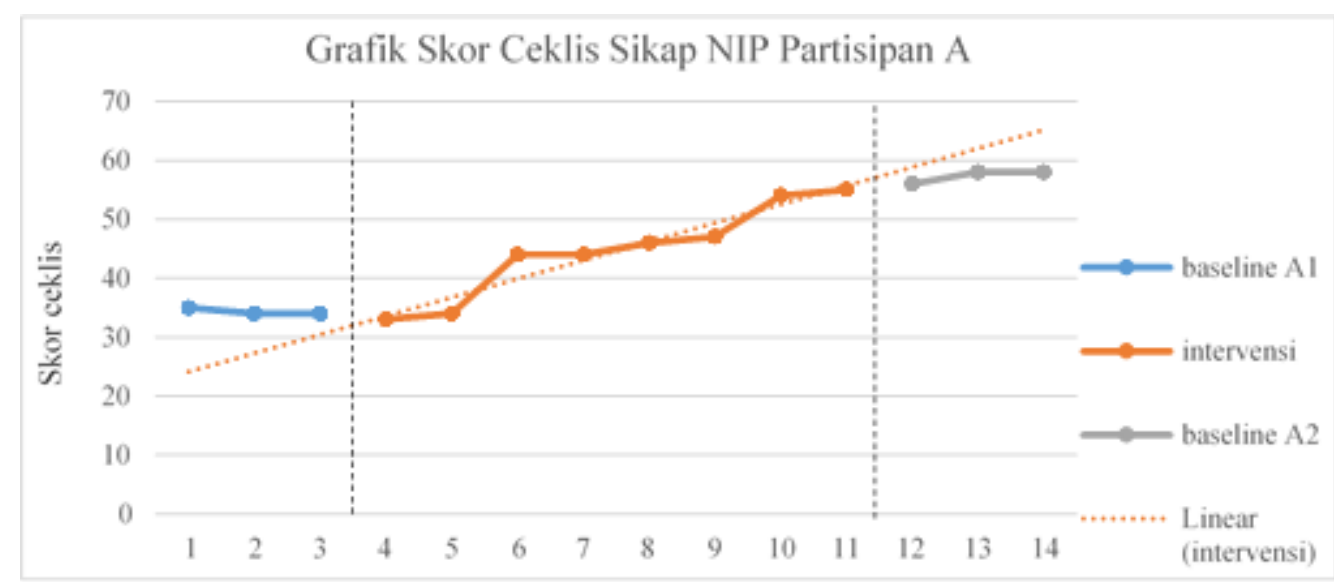

Grafik 5. Hasil ceklis harian sikap NIP (Cek manipulasi)

Adanya perubahan terhadap hasil kesejahteraan psikologis partisipan A ternyata memiliki kesesuaian dengan perubahan hasil kualitas sikap NIP pada diri partisipan. Berdasarkan perhitungan hasil skor rerata ceklis sikap harian NIP, diketahui bila partisipan mengalami kenaikan dari skor $M=34,3$ pada fase baseline 1, kemudian meningkat menjadi $M=44,6$ pada fase intervensi dan terus meningkat menjadi $M=$ 57,3 pada fase baseline 2 . Adanya peningkatan hasil skor rerata tersebut menunjukkan bila terjadi peningkatan sikap NIP pada diri partisipan.

Peningkatan sikap NIP dalam diri partisipan A juga dapat terlihat dari arah tren garis linear seperti yang terdapat pada grafik 5. Kenaikan mulai terjadi sejak fase intervensi diberikan kepada partisipan, terutama mulai dari pertemuan ketiga. Kenaikan sikap NIP juga terus terlihat hingga fase baseline 2, yaitu fase setelah intervensi selesai diberikan.Bila dianalisis secara lebih terperinci terhadap aspek-aspek dalam NIP, diketahui bila partisipan mengalami peningkatan pada ketiga aspek dalam NIP. Berdasarkan perhitungan skor rerata aspek sabar, diketahui bila partisipan A mendapatkan skor $M=10$ pada fase baseline 1 , meningkat menjadi $M=14,1$ pada fase intervensi dan semakin meningkat menjadi $M=18,7$ pada fase baseline 2. Untuk perhitungan skor rerata aspek syukur, diketahui skor partisipan bergerak dari $M=13,3$ pada fase baseline 1, menjadi $M=15,5$ pada fase intervensi dan $M$ = 19 pada fase baseline 2. Untuk aspek sikap

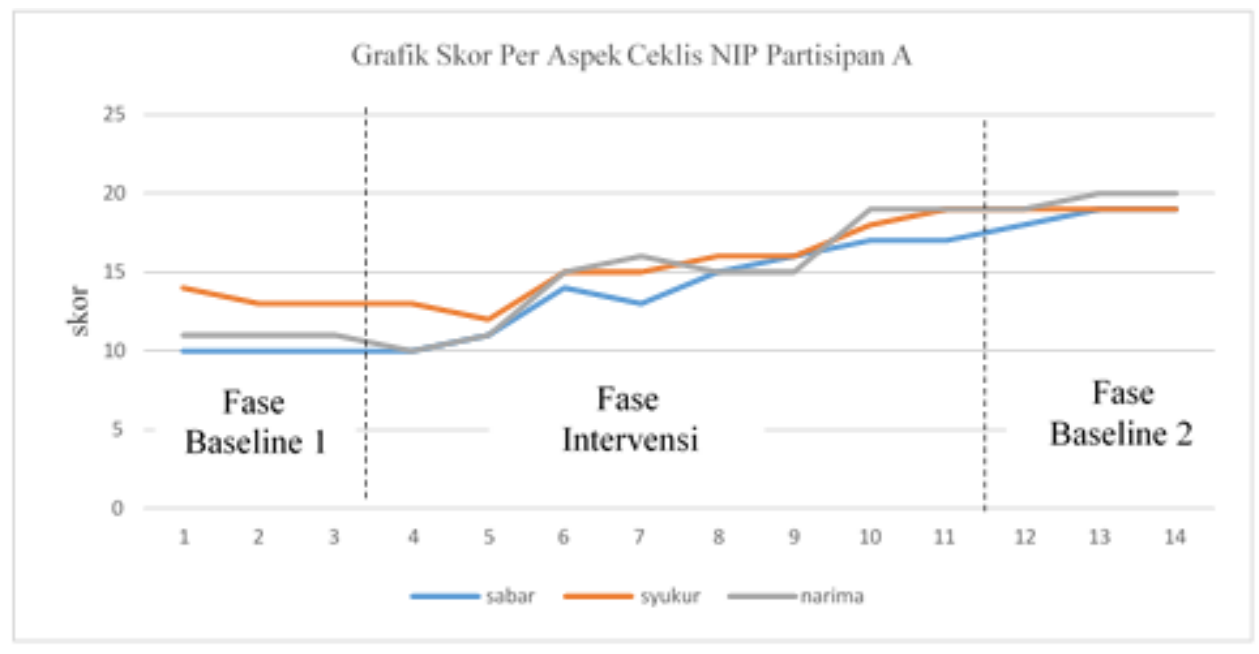

Grafik 6. Hasil skor setiap aspek NIP Partisipan A 
narima, diketahui bila partisipan memperoleh hasil rerata skor $M=11$ pada baseline 1, kemudian naik menjadi $M=15$ pada fase intervensi dan $M=19,7$ pada fase baseline 2.

Apabila dilihat dari hasil grafik skor per aspek NIP, seperti yang tertera dalam grafik 6, terlihat bila partisipan A memang mengalami peningkatan pada ketiga aspek dalam NIP. Meskipun ketiganya sama-sama mengalami peningkatan, sikap sabar dan sikap narima merupakan dua sikap yang terlihat mengalami peningkatan yang lebih banyak dibandingkan dengan sikap syukur. Hasil gambar grafik juga menunjukkan bila peningkatan aspek-aspek dalam NIP partisipan mulai terlihat sejak awal intervensi hingga fase baseline 2 .

Dari hasil tersebut dapat disimpulkan bahwa terapi NIP dapat meningkatkan sikapsikap NIP yang berupa sikap sabar, sikap syukur dan sikap narima dalam diri partisipan, yang kemudian berpengaruh pula dalam peningkatan kondisi kesejahteraan psikologis.

\section{Analisis deskriptif}

Data deskriptif diperoleh dari hasil lembar kerja, wawancara dan hasil observasi tertulis. Berdasarkan data deskriptif partisipan, partisipan mengungkapkan bila dirinya memiliki keinginan untuk mendapat anak sejak lama. Hanya saja, meskipun telah melakukan banyak usaha baik medis ataupun non medis, A belum juga berhasil mendapatkan keturunan. Hal tersebut menyebabkan munculnya perilaku mempertanyakan dan menyalahkan diri sendiri atas kondisi yang ada. Partisipan juga mengungkapkan bila kondisinya yang sulit memiliki anak, terkadang menyebabkan adanya perasaan kesal dan cemas terhadap diri sendiri. Hal tersebut mengindikasikan adanya permasalahan dalam dimensi kesejahteraan psikologis yaitu penerimaan terhadap diri.
A juga menyebutkan bila kondisi belum memiliki anak disertai dengan keinginan yang besar untuk memilikinya, membuat adanya permasalahan dalam hubungan sosial. A menyebutkan bila suami sampai saat ini masih saja merokok dan melakukan gaya hidup tidak sehat lainnya sehingga dirasa A dapat memengaruhi keberhasilan dalam memiliki anak. Hal tersebut membuat A merasa kesal dan sering kali mengomel serta marah kepada suami. A juga mengungkapkan bila kondisi belum memiliki anak menyebabkan A menghindari teman ataupun keluarga yang sering kali nyinyir dan menanyainya seputar kehamilan. Adanya hal-hal tersebut mengindikasikan A memiliki permasalahan dalam dimensi kesejahteraan psikologis yang berupa hubungan positif dengan orang lain. Dalam mengatasi emosi-emosi negatif dalam diri, A biasanya berusaha melupakan kejadian negatif yang terjadi, menghindari kondisi yang sekiranya dapat memunculkan emosi negatif dan melampiaskan dengan mengomel. A mengatakan bila cara tersebut tidak banyak membantu dan malah terkadang membuat munculnya permasalahan yang lain. Hal tersebut yang kemudian mendorong A untuk mengikuti proses terapi supaya dapat belajar cara mengatur emosi dan mengungkapkan emosi dengan lebih tepat.

Selama proses terapi, pada pertemuan pertama dan kedua, partisipan mampu menyadari emosi-emosi yang ada dalam dirinya. Partisipan A menyadari bahwa dirinya masih menyimpan rasa sedih, rasa marah, perasaan bersalah dan berbagai emosi lainnya. Kesadaran akan emosi-emosi tersebut muncul ketika partisipan diberikan proses rileksasi dan pemaknaan. Kesadaran akan emosi tersebut mendorong partisipan untuk lebih terbuka dalam bercerita kepada terapis selama proses terapi. Hal tersebut terlihat dari antuasisme dan keterbukaan 
partisipan untuk kembali bercerita seusai proses rileksasi.

Pada pertemuan ketiga partisipan mengungkapkan bila dirinya mulai mencoba menerapkan pengetahuan tentang sikap sabar yang didapatkan dari hasil terapi paska pertemuan kedua. Hanya saja terkadang partisipan masih lupa bagaimana cara menerapkannya, sehingga membuatnya ragu-ragu dalam menerapkannya. Pertemuan ketiga membuat partisipan

merasa semakin yakin dan termotivasi untuk menerapkan sikap sabar. Pada pertemuan keempat dan kelima, partisipan mengungkapkan bila sikap syukur merupakan hal yang jauh lebih mudah untuk dipahami dan diterapkan dibanding sikap sabar. Meskipun demikian, pertemuan keempat dan kelima membuat partisipan merasa semakin paham dan termotivasi untuk menerapkan sikap syukur dikarenakan adanya dukungan dan penguatan dari terapis

Pada pertemuan keenam, partisipan mengungkapkan bila dirinya teringat kembali mengenai arti dari penerimaan. Partisipan juga mengungkapkan bila sikap sabar, syukur dan menerima membawa dampak positif dalam dirinya, salah satunya mampu lebih sabar dalam menghadapi suami dan mampu mengajak suami untuk bersama-sama menerapkan sikap sabar dan syukur dalam menghadapi kondisi yang terjadi. Pada pertemuan ketujuh, partisipan mengungkapkan bila dirinya lebih mampu menerima kondisi yang terjadi di sekitarnya. Sebagai contoh, saat mendengar temannya hamil, partisipan tidak merasakan iri namun dapat ikut berbahagia. Partisipan merasa mampu menerima kondisi dirinya dan suami yang belum dapat hamil. Pemahaman yang dimiliki partisipan juga membuat partisipan merasa yakin saat akan mengajarkannya kepada suami.

Di pertemuan kedelapan, partisipan mengutarakan bila dirinya merasakan banyak manfaat dari terapi yang telah dilakukan. Partisipan merasa sebelum ikut terapi, dirinya sangat sensitif terhadap masalah memiliki momongan. Namun, sekarang partisipan merasa sudah lebih jauh dapat menerima kondisi tersebut sehingga merasa semakin nyaman dan semakin bersemangat untuk berusaha. Partisipan juga mengungkapkan dirinya sudah mampu mengontrol emosi dan mengurangi kemarahannya kepada suami sehingga hubungan di antara mereka berdua membaik.

Pada wawancara akhir di fase baseline 2 partisipan A mengungkapkan bila dirinya masih terus menerapkan apa yang Ia dapatkan dari proses terapi. A merasa bahwa apa yang dipelajari dari terapi kini merupakan bagian dari dirinya, dan apa yang dilakukannya tersebut (menerapkan sikapsikap NIP) memberikan perasaan nyaman dan tenang dalam diri. Dari keseluruhan proses terapi, A menyatakan bahwa proses pemberian materi, pemaknaan diserta rileksasi merupakan tiga hal yang paling berkesan dan bermanfaat dalam dirinya. Bahkan A juga mengajarkan dan menularkan ketiga hal tersebut kepada suami serta temanteman yang dirasa memiliki kondisi serupa. A mengungkapkan bila dirinya masih terus merasakan manfaat yang didapat dari proses terapi yaitu mampu mengontrol emosi dan mampu menerima kondisi belum memiliki anak dengan perasaan tenang.

\section{Diskusi}

Studi ini dilakukan untuk menguji efektivitas dari Terapi Narima Ing Pandum untuk meningkatkan kesejahteraan psikologis pada wanita menikah dengan gangguan fertilitas idiopatik. Dari hasil analisis visual inspection kedua partisipan, diketahui bahwa kedua partisipan mengalami peningkatan kondisi kesejahteraan psikologis seiring dengan adanya peningkatan kualitas sikap-sikap NIP 
dalam diri partisipan. Peningkatan akan kesejahteraan psikologis dan sikap-sikap dalam NIP dapat terlihat dari perubahan skor rerata antara satu fase dengan fase yang lain serta perubahan arah garis tren linear dalam hasil grafik.

Adanya perubahan kondisi kesejahteraan psikologis yang selaras dengan perubahan kualitas sikap-sikap NIP (sabar, syukur dan narima) dalam diri individu, sesuai dengan berbagai hasil dari penelitian yang telah ada. Penelitian mengenai sikap sabar dikemukakan oleh Schnitker (2012) menyebutkan bahwa, adanya peningkatan sikap sabar terbukti dapat menurunkan kondisi depresif, menurunkan tingkat emosi negatif serta meningkatkan kemampuan untuk menghadapi tantangan yang ada dalam diri individu. Hal tersebut juga sesuai dengan kondisi partisipan A yang menyatakan bahwa peningkatan sikap sabar dalam dirinya karena terapi NIP dirasakan membantu A dalam menghadapi suami dan memperbaiki hubungan di antara mereka berdua. Begitu pula dengan partisipan $\mathrm{N}$ yang mengungkapkan bila terapi NIP mampu membantunya merasa lebih legawa dan mengatur emosinya yang selama ini cenderung fluktuatif

Adanya peningkatan kualitas akan sikap syukur juga telah terbukti dapat menciptakan perasaan bahagia (Emmons \& Stern, 2013) serta menurunkan tingkat stres dan depresi pada seorang individu (Emmons \& Stern, 2013; Gavian, 2011). Hal tersebut pun sesuai dengan kondisi partisipan $\mathrm{N}$ yang merasa jauh lebih legawa dan partisipan A yang merasa bahagia dan nyaman setelah proses intervensi diberikan. Penelitian mengenai penerimaan, sesuatu yang paling ditekankan dalam penelitian ini, juga menemukan bahwa adanya peningkatan penerimaan dalam diri individu dapat membawa dampak positif pada kesejahteraan psikologis individu yang sedang menghadapi kondisi sulit (Fava \&
Tomba, 2009; Moghanloo, Moghanloo \& Moazezi, 2015; Garcia et al., 2014). Hal tersebut selaras dengan apa yang dialami dan didapatkaan partisipan dalam penelitian ini. Partisipan A mengungkapkan bila yang semula sensitif terhadap pembicaraan seputar isu memiliki anak, menjadi lebih jauh lebih nyaman dan semakin bersemangat untuk berusaha mengikuti program kehamilan di saat dirinya mampu menerima kondisi tersebut.

Dari penjelasan di atas dapat disimpulkan bahwa Terapi NIP dalam penelitian ini tidak hanya mengurangi distres pada diri partisipan. Terapi NIP juga terbukti dapat menumbuhkan sikap positif baik terhadap diri sendiri ataupun terhadap orang lain dan lingkungan sekitar, mampu melakukan pertumbuhan dan perkembangan diri yang berkelanjutan serta memiliki tujuan. Hal tersebut sesuai dengan teori mengenai ciri-ciri adanya kesejahteraan psikologi yang baik menurut Ryff (2014). Berdasarkan hal tersebut, hipotesis dalam penelitian ini diterima.

Dalam pelaksanaan intervensi, terdapat beberapa hal yang dirasa menunjang keberhasilan terapi untuk mencapai tujuan dari penelitian ini diadakan. Hal yang pertama adalah adanya sesi bercerita dan berdiskusi sebagai suatu sarana katarsis bagi partisipan. Proses katarsis berlangsung selama proses terapi diadakan, terutama pada pertemuan sesi pertama. Proses katarsis diketahui membawa banyak manfaat pada partisipan yaitu menimbulkan adanya perasaan lega pada diri partisipan dan membantu partisipan menemukan perasaan-perasaannya yang selama ini terabaikan. Hal tersebut sesuai manfaat dari katarsis yaitu mengurangi simptom depresi dan kecemasan serta mampu meningkatkan pemahaman individu atas kondisi emosional yang dimiliki (Powell, 2007; Qonitatin, Widyawati \& Asih, 2011). 
Hal berikutnya adalah adanya proses pemberian materi pada partisipan. Proses pemberian materi diketahui membantu partisipan untuk memahami secara lengkap dan komprehensif terkait dengan topik-topik yang diangkat. Dalam proses ini, kedua partisipan merasa bila dirinya menjadi lebih tahu dan paham mengenai seluk beluk sikapsikap NIP yaitu sabar, syukur dan narima. Hal tersebut sesuai dengan manfaat dari pemberian materi yaitu memberikan pengetahuan kepada individu terkait dengan kondisi dirinya sehingga individu lebih memahami keadaan diri sendiri, mampu melakukan tindakan preventif ataupun kuratif (Lukens \& McFarlane, 2004).

Rileksasi dalam terapi ini juga dirasa sebagai salah satu hal yang menunjang keberhasilan terapi NIP. Partisipan A merasa rileksasi mampu membantunya mengendalikan emosi yang cenderung fluktuatif. Hal yang dirasakan oleh partisipan tersebut selaras dengan penelitian Ali \& Hasan (2010) yang menemukan bahwa rileksasi mampu mengurangi ketegangan otot sehingga dapat membantu individu mengurangi rasa cemas dan merasa lebih tenang.

Pada saat proses intervensi selesai diberikan lalu dilakukan pengukuran dan follow up kurang lebih selama tiga kali, diketahui bila kedua partisipan tidak mengalami penurunan kesejahteraan psikologis. Selaras dengan hal tersebut, kondisi sikap-sikap NIP dalam diri partisipan juga tidak mengalami penurunan. Bahkan, kedua partisipan mengalami kondisi peningkatan bila dibandingkan dengan kondisi intervensi. Berdasarkan hasil wawancara akhir dengan partisipan, diketahui bila kedua partisipan berusaha menjadikan nilai-nilai NIP sebagai nilai dalam hidup untuk terus dilakukan. Dengan bersikap sesuai dengan nilai-nilai NIP, partisipan merasa nyaman dan tenang dalam menghadapi kejadian sehari-hari. Hal tersebut membuktikan bahwa efek dari terapi
NIP dapat bertahan pada diri partisipan selama sikap-sikap NIP masih terus dilakukan.

Hal yang menarik perhatian dalam penelitian ini adalah adanya penurunan skor rerata kesejahteraan psikologis pada partisipan N. Meskipun telah terjadi peningkatan skor rerata dari fase intervensi hingga fase baseline 2, kedua skor rerata tersebut tetap lebih rendah apabila dibandingkan dengan skor rerata pada fase baseline 1. Kondisi lain yang menarik dari partisipan $\mathrm{N}$ adalah tidak semua aspek NIP dalam diri partisipan meningkat selama mengikuti terapi. Hanya aspek sikap sabar dan sikap syukur partisipan yang meningkat, sedangkan aspek sikap narima dalam diri partisipan cenderung menurun seiring dengan jalannya terapi.

Adanya kondisi tersebut diduga karena $\mathrm{N}$ kurang memiliki kesiapan (readiness) dalam mengikuti proses terapi, meskipun sebenarnya $\mathrm{N}$ telah memiliki kemauan (willingness) yang baik. Peneliti menduga ketidaksiapan $\mathrm{N}$ sebenarnya sudah terjadi sejak baseline 1, ditunjukkan dengan sikap sering mengulang-ulang pernyataan bahwa dirinya baik-baik saja. Hal tersebut yang sekiranya mungkin menyebabkan terjadinya faking-good dalam proses pengisian ceklis sehingga hasil skor ceklis pada fase tersebut sangat tinggi. $\mathrm{N}$ kemudian juga masih menunjukkan ketidaksiapan di awal proses terapi sehingga $\mathrm{N}$ masih sering menyangkal disaat diberikan refleksi emosi dan saat terapis mencoba menyimpulkan hasil pembicaraan.

Secara lebih jauh, Ogrodniczuk et al. (2009) menyebutkan bila kesiapan dapat memengaruhi dimensi-dimensi lain dalam diri individu seperti kemauan (willingness), hasrat (desire) dan tingkat distres. Oleh karena itu, ketika individu tidak siap dalam mengikuti proses psikoterapi maka hasilnya dapat dipastikan tidak sesuai dengan arah dari terapi tersebut dirancang. 
$\mathrm{N}$ baru menunjukkan kesiapan sesungguhnya pada pertemuan ke 4. Pada pertemuan tersebut $\mathrm{N}$ mulai mengizinkan terapis dan dirinya sendiri untuk berproses bersama dalam terapi. $\mathrm{N}$ tidak lagi menunjukkan adanya penolakan dan penyangkalan akan emosi dalam dirinya. Munculnya kesiapan tersebut yang disinyalir mendorong $\mathrm{N}$ untuk mengisi ceklis secara jujur, sesuai dengan kondisi emosi dan pikiran yang $\mathrm{N}$ miliki.

Terapi NIP dalam penelitian ini, juga tidak terlepas dari hal-hal di luar terapi yang dapat menjadi ancaman validitas internal penelitian, seperti kondisi kedua partisipan yang bekerja yang menyebabkan pelaksanaan intervensi menjadi berubah dari waktu yang seharusnya, suasana tempat terapi yang terkadang kurang mendukung jalannya terapi serta waktu yang cenderung terbatas dalam melakukan proses intervensi.

\section{Kesimpulan}

Hasil penelitian yang telah dilakukan menunjukkan bahwa Terapi Narima Ing Pandum terbukti dapat meningkatkan kesejahteraan psikologis pada wanita menikah dengan gangguan fertilitas idiopatik. Hal tersebut dapat terlihat dari peningkatan skor rerata kesejahteraan psikologis pada partisipan setelah mengikuti terapi.

\section{Saran}

Bagi peneliti selanjutnya dapat memperjelas definisi operasional dalam ceklis NIP yang digunakan, seperti memastikan bahwa partisipan penelitian tidak hanya sekedar suku Jawa dan paham bahasa Jawa, namun juga memahami serta menjalankan nilai-nilai Jawa. Mencobakan kembali pada kriteria partisipan yang sama untuk melihat keefektivan dari terapi NIP lebih lanjut.

Bagi partisipan penelitian dapat menerapkan narima ing pandum secara terus- menerus dalam kehidupan sehari-hari. Hal tersebut dikarenakan NIP merupakan sikap yang perlu dibentuk dengan pembiasaan.

\section{Daftar Pustaka}

Ali, U., \& Hasan, S. (2010). The effectiveness of relaxation therapy in the reducing of anxiety related symptoms: A case study. International Journal of Psychological Studies, 2(2), 202-208. doi: $10.5539 /$ ijps.v2n2p202

Bratawijaya, T. W. (1997). Mengungkap dan mengenal budaya Jawa. Jakarta: PT. Pradnya Paramita.

Dermatoto, A. (2008). Dampak infertilitas terhadap perkawinan: Suatu perspektif gender. Laporan Penelitian Fakultas Ilmu Sosial dan Ilmu Politik (Tidak diterbitkan). Surakarta: Universitas Sebelas Maret.

Draye, M. A., Wood, N. F., \& Mitchell, E. (2009). Coping with infertility in couples: Gender differences. Health Care for Women International Journal, 9, 163-175. doi: 10.1080/0739933880 $\underline{9515815}$

Duvall, E., \& Miller C. M. (1985). Marriage and family develompent $6^{\text {th }} \mathrm{Ed}$. New York: Harper \& Row Publisher.

Emmons, R. A., \& Stern, R. (2013). Gratitude as psychotherapeutic intervention. Journal of Clinical Psychology in Session, 8(69), 846-855. doi: 10.1002/jclp.22020

Endraswara, S. (2012). Falsafah hidup Jawa: Menggali mutiara kebijakan dari intisari filsafat kejawen. Yogyakarta: Cakrawala.

Fava, G. A., \& Tomba, E. (2009). Increasing psychological well-being and resilience by psychotherapeutic methods. Journal of Personality, 6(77). 1467-1934. doi: 10.1111/j.14676494.2009.00604.x

Garcia, D., Nima, A. A., \& Kjell, O. N. E. (2014). The affective profile, 
psychological well-being and harmony: Enviromental mastery and self-acceptance predict the sense of a harmonious life. Peer], 1, 1-21. doi: 10.7717/peerj.259

Gavian, M. E. (2011). The effect of relaxation and gratitude intervention on stress outcome. Dissertation

(Unpublished). Minnesota: The University of Minnesota.

Haica, C. C. (2013). Gender differences in quality of life, intensity of dysfunctional attitudes, unconditional self-acceptance, emotional distress and dyadic adjustment of infertile couples. Procedia-Social and Behavioral Sciences, 78, 506-510. doi: 10.1016/j.sbspro .2013 .04 .340

Hartoyo, Latifah, M., \& Mulyani, S. R. (2011). Studi nilai anak, jumlah anak yang diinginkan dan keikutsertaan orang tua dalam program KB. Jurnal Ilmu Keluarga \& Konsumen, 4(1), 37-45.

Hidayah, N. (2012). Nilai anak, stres infertilitas dan kepuasan perkawinan pada wanita yang mengalami infertilitas. Insight, Jurnal Ilmiah Psikologi Universitas Mercubuana Yogyakarta. Yogyakarta: Universitas Mercubuana.

Hiferi (Himpunan Endokrinologi Reproduksi dan Fertilitas Indonesia), Perfitri (Perhimpunan Fertilisasi In Vitro Indonesia), IAUI (Ikatan Ahli Urologi Indonesia), \& POGI (Perkumpulan Obstetri dan Ginekologi Indonesia). (2013). Konsensus penanganan infertilitas. Jakarta : HIFERI.

Lukens, E. P., \& McFarlane, W. R. (2004). Psychoeducation as evidence-based practice: Considerations for practice, research and policy. Brief Treatment and Crisis Intervention, 4(3). Oxford: University Press.
Moeloek, F. A. (1986). Aspek psikologi \& sosiologi kontrasepsi. Jakarta: PKBI.

Moghanloo, V. A., Moghanloo, R. A., \& Moazezi, M. (2015). Effectiveness of acceptance and commitment therapy for depression, psychological wellbeing and feeling of guilt in 7-15 years old diabetic children. Iran Journal Pediatric, 4(25), 1-6. doi: $\underline{10.5812}$ Lijp. 2436

Ogrodniczuk, J. S., Joyce, A., \& Piper, W. E. (2009). Development of the readiness for psychotherapy index. The Journal of Nervous and Mental Disease, 197(6), 427-33. doi: 10.1097/NMD.0b013e31 $\underline{81 \mathrm{a} 61 \mathrm{c} 56}$

Park, N. K., \& Hill, P. W. (2014). Is adoption an option? The role of importance of motherhood and fertilitty helpseeking in considering adoption. Journal of Family Issues, 5(35), 601-626. doi : $\underline{10.1177 / 0192513 \times 13493277}$

Passer, M. W., \& Smith, R. E. (2007). Psychology the science of mind and behavior 3rd ed. New York: McGraw Hill.

Peterson, B. D., Newton, C. R., Rosen, K. H., \& Skaggs, G. E. (2006). Gender differences in how men and women who are referred for IVF cope with infertility stress. Human Reproduction Journal, 21(9), 2443-2449. doi: 10.1093/humrep/de1145

Pinel, J. P. J. (2009). Biopsikologi, Edisi ketujuh. Yogyakarta: Pustaka Pelajar.

Powell, E. (2007). Chatarsis in psychology and beyond: A historic overview. Retrieved from page.com/cathar.htm

http://primal-

Prasetyo, N. H. (2014). Program intervensi narima ing pandum untuk meningkatkan kesejahteraan psikologis keluarga pasien skizofrenia. Tesis (tidak diterbitkan). Yogyakarta: Universitas Gadjah Mada. 
Qonitatin, N., Widyawati, S., \& Asih, G. Y. (2011). Pengaruh katarsis dalam menulis ekspresif sebagai intervensi depresi ringan pada mahasiswa. Jurnal Psikologi Undip, 9(1).

Rahmat. (2017). Alihbahasa dan interpretasi naskah Babad Blarutan. (Tidak diterbitkan). Yogyakarta: Pakualaman.

Rascanu, R., \& Vladica, S. (2012). Attitudinal and emotional structures spesific for infertile women. Procedia - Social and Behavioral Sciences, 33, 100-103. doi: 10.1016/j.sbspro.2012.01.091

Ryff, C. D. (2014). Psychological well-being revisited: Advances in the science and practice of eudaimonia. Psychotherapy and Psychosomatics, 83, 10-28.

Ryff, C. D. (1989). Happiness is everything or is it? Explorations on the meaning of psychological well being. Journal of Personality \& Social Psychology, 5, 10691081.

Saktimulya, S. R. (2016). Naskah-naskah skriptorium Pakualaman, Periode Paku Alam II (1830-1858). Jakarta: Gramedia.

Schnitker, S. A. (2012). An examination of patience and wellbeing. Journal of Positive Psychology, 7, 263-280.

Sigar, A. (2008). Koping istri dalam merespon kegagalan terapi infertilitas di RSUP Dr. Sardjito Yogyakarta. Tesis (Tidak diterbitkan). Yogyakarta: Universitas Gadjah Mada.

Singarimbun, M., Darroch, R.K., \& Meyer, P.A. (1977). Nilai anak: Hasil penelitian di Jawa. Laporan Penelitian (tidak diterbitkan). Yogyakarta: PPS Kependudukan UGM.

Smolak, L. (1993). Adult development. New Jersey: Pearson.

Subandi. (2011). Sabar: Sebuah konsep psikologi. Jurnal Psikologi, 3(2), 215227
Sulaksono, D. (2014). Filsafat Jawa. Surakarta : Cakrawala Media.

Suratno, P., \& Astiyanto, H. (2009). Gusti ora sare: 90 mutiara nilai kearifan budaya Jawa. Yogyakarta: Adiwacana.

Tseng, W. (1999). Culture and psychotherapy: A review and practical guidelines. Transcultural Psychiatry Article, 36(2), 131-179.

Tuzer, V., Tuncel, A., Goka, S., Bulut, S. D., Yuksel, F. V., Atan, A., \& Goka, E. (2010). Marital adjustment and emotional symptoms in infertile couples: Gender differences. Journal of Turkish Medical Science, 2(40), 229-237. doi: 10.3906/sag-0901-17

Oktriyanto, Puspitawati, H., \& Muflikhati, I. (2015). Nilai anak dan jumlah anak yang diinginkan pasangan usia subur di wilayah pedesaan dan perkotaan. Jurnal Ilmu Keluarga \& Konsumen, 8(1), 1-9.

White, T. M., Gibbons, M. B., \& Schamberger, M. (2006). Cultural sensitivity and supportive expressive psychotherapy: An integrative approach to treatment. Am J Psychother. 60(3), 299316.

Wood, A. M., Froh, J. J., \& Geraghty, A. W. A. (2010). Gratitude and wellbeing: A review and theoritical integration. Clinical Psychology Review. doi: $\underline{10.1016 / j . c p r .2010 .03 .005}$

Wood, A. M., Joseph, S., \& Maltby, J. (2008). Gratitude uniquely predicts satisfaction with life: Incremental validity above the domains and facets of the five factor model. Personality and Individual Differences, 45(1), 49-54. doi: 10.1016/j.paid.2008.02.019

Xiaoli, S., Mei, L., Junjun, B., Shu, D., Zhaolian, W., Jin, W., Ju, Q., Wanli, S., Huali, Z., Li, J., Dong, L., Li, P., \& Xiaojin, H. (2015). Assessing the quality of life of infertile chinese women: A cross-sectional study. 
Taiwanese Journal of Obstetric $\mathcal{E}$ Gynecology, 55, 244-250. doi: 10.1016/j.tog.2015.06.014

Zulyet, E. (2014). Penerapan program intervensi narima ing pandum (NIP) untuk menurunkan expressed emotion keluarga orang dengan skizofrenia (ODS). Tesis (tidak diterbitkan). Yogyakarta: Universitas Gadjah Mada. 